\title{
COLLABORATION BETWEEN WEST TEXAS A\&M UNIVERSITY, FH JOANNEUM, AND MEDICAL UNIVERSITY OF GRAZ ON WATER QUALITY IMPROVEMENT FOR RURAL AREAS OF INDIA
}

\author{
Roy J. Issa ${ }^{* *}$, Angela P. Schoepfer ${ }^{2}$, Andrea Grisold ${ }^{3}$, Andreas Schoepfer ${ }^{4}$ \\ ${ }^{1}$ West Texas A\&M University, Canyon, TX 79016, USA \\ ${ }^{2}$ FH JOANNEUM/University of Applied Sciences, Graz, 8020, Austria \\ ${ }^{3}$ Medical University of Graz, Graz, 8036, Austria \\ ${ }^{4}$ University Hospital, Graz, 8036, Austria
}

\begin{abstract}
In this project, a group of senior mechanical engineering students from West Texas A\&M University were asked to design a ceramic clay filter system with anti-microbial protection capability for purification of drinking water in rural communities in India. The project started at West Texas A\&M University and concluded at FH JOANNEUM in Graz, Austria with a group of students from Production Technology and Organization Program. Students experimented with a mixture of different clay powder material and saw dust concentrations before arriving at the optimal conditions to create the porous clay filters using clay with saw dust concentrations ranging from 22.5 to $27.5 \%$ by weight. Based on that, 4 different types of clay filters were created. In addition to creating traditional clay filters, filters with silver nanoparticles were also formed by impregnating the clay-saw dust mixture with the nanoparticles before the filters were fired in the kiln. Tests were conducted on the filters for their effectiveness in reducing the turbidity of muddy water, and also for the benefit of having silver nanoparticles as an anti-bacterial agent. The filters were very effective in reducing the turbidity of muddy water from 950 to 0.45 NTU. E. coli bacteria tests showed the silver-embedded clay filters reduced the E. coli bacteria concentration in contaminated water from $6.5 \times 10^{7}-5.5 \times 10^{8}$ cells $/ \mathrm{ml}$ to $0-1.26 \times 10^{6}$ cells $/ \mathrm{ml}$. This international exposure provided an opportunity for the students to communicate effectively with a range of audiences, an ABET student learning outcome and an essential capability to have as an engineer nowadays.
\end{abstract}

KEY WORDS: Silver nanoparticles, Clay filters, Permeability, Turbidity, E. coli bacteria

\section{INTRODUCTION}

According to a 2015 database report published by the World Health Organization (WHO) and the United Nations International Children's Emergency Fund (UNICEF) on the world's progress regarding sanitation and drinking water, approximately 663 million people worldwide did not have access to an improved drinking water source (including contaminated wells, springs and surface water) [1]. According to the report, 13\% of the global population (almost 1 billion people) continues to practice open defecation. Sanitation coverage worldwide was at $68 \%$ in 2015 , which is below the target set at $77 \%$ by WHO. Forty-seven countries have sanitation coverage that is less than $50 \%$ as Fig. 1 shows. Countries that are most affected include India, Afghanistan, and central African countries.

*Corresponding Author: rissa@wtamu.edu 


\section{口}

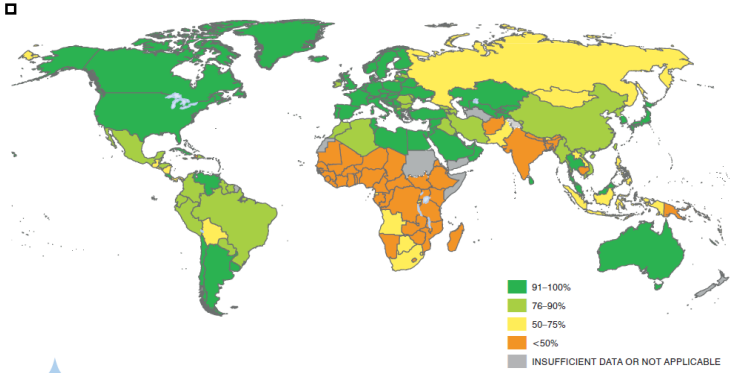

Fig. 1 Proportion of sanitation coverage worldwide in 2015.

(Adapted from WHO \& UNICEF, 2015 [1])

There are several methods to purify water. This can be achieved either by the use of a physical process (filtration, sedimentation, distillation), a biological process (active carbon), or a chemical process (chlorination, ultraviolet light). One of those techniques, ceramic/clay filtration, has been very effective in removing dirt and bacteria out of the water due to the small pores associated with the material. The technology is quite old, but is economical. It was used extensively during the Victorian era [2]. The system consists of a simple ceramic vessel, such as a pot, in which contaminated water is poured. As the water filters through the walls of the ceramic pot, it collects into a container that is placed directly below it. Other uncommon techniques, such as the use of silver metal, were implemented in ancient times to stop the buildup of microbes in stored water due to its silver's antimicrobial effects [3]. For example, Alexander the Great used silver vessels to store drinking water during his war campaigns [4]. Studies [5, 6] show the release of silver ions $\mathrm{Ag}^{+}$ into contaminated water can produce free radicals resulting in the generation of reactive oxygen species, ROS, that lead to the destruction of the cellular walls of the bacteria (Fig. 2). Recent studies [7] have also been performed on the effect of Ag nanoparticles on inhibiting the growth of bacteria in waste water biofilms, and in inhibiting bacterial growth coupled with the use of ceramic filters [8].

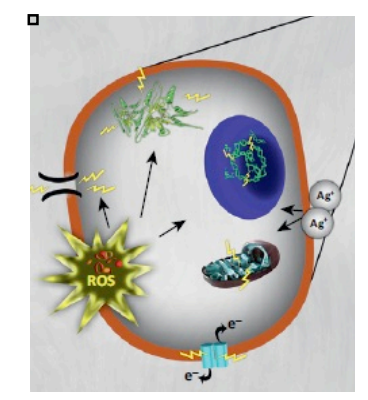

Fig. 2 Toxicology effect of $\mathrm{Ag}^{+}$ions in bacterial biofilms.

(Adapted from Hajipour et al., 2012 [6])

The purpose of this project is to conduct a detailed performance study to design a ceramic clay filtering system with anti-microbial protection capability for purification of drinking water. The system is to be easily manufactured in a developing country.

The project started at West Texas A\&M University (WTAMU) and concluded at FH JOANNEUM in Graz, Austria. FH JOANNEUM is a university of applied sciences where FH stands for Fachhochschule, a German/Austrian tertiary education institution that emerged from traditional engineering schools. Fachhochschule differs from the technical university through its more practical emphasis. The Fachhochschule university builds a strong relationship with industry. In the Production Technology and Organization Program (PTO) at FH JOANNEUM, students' admission in the engineering program is contingent on maintaining a continuous appointment in industry as engineering interns. 


\section{PROJECT INITIATION AT WEST TEXAS A\&M UNIVERSITY}

The project was initiated in the fall semester of 2017 when it was assigned as a project in the Thermal-Fluid Design course, offered at the senior year in the Mechanical Engineering Program at WTAMU. In ThermalFluid Design, students apply heat transfer and fluid mechanics concepts in designing thermal-fluid systems. Emphasis is placed on performing analysis, generating and evaluating multiple solutions, including optimization, economic considerations and sustainability in the engineering design. Students learning outcomes related to this course include all of ABET accreditation criteria [9]: 3(1-7) and particularly those dealing with problem-solving, functionality, teamwork, and communications skills.

The class at WTAMU consisted of 16 students divided into 4 groups, each having equal number of students. The groups were given the task to design their own clay filters, and each group conducted its own tests to evaluate the clay filters' performance. At the end of the 2017 fall semester, the best 4 clay filter configurations were selected from among 48 filters that were designed by the 4 groups. Figure 3 shows the variety of clay filter sizes created during this initial phase of the project. The filters were created in the shape of disks having (initially) a diameter of $7.62 \mathrm{~cm}$, and of three different thicknesses: $0.75,1.5$ and $2.25 \mathrm{~cm}$.

Filters were made of clay material that was mixed with an appropriate amount of fine saw dust and particle size. During the 2017 fall semester, students experimented with five different types of clay powder material: red art, off-white clay body, Hirondelle stoneware, Michael Simon stoneware no. 2, and Val Cushing offwhite/grey. Saw dust composition ranging from $22.5 \%$ to $30 \%$ by weight was also tested. Sieves of two sizes \#16 (1180 microns) and \#30 (600 microns) were used to strain the clay to a finer particle size. The clay-saw dust mixture was slowly fired in a kiln (Fig. 4) in the ceramics lab at WTAMU to a desired temperature of 700 ${ }^{\circ} \mathrm{C}$. At this temperature the dust particles completely burned and a porous material was formed. The kiln transient temperature during the firing process in shown in Fig. 5.

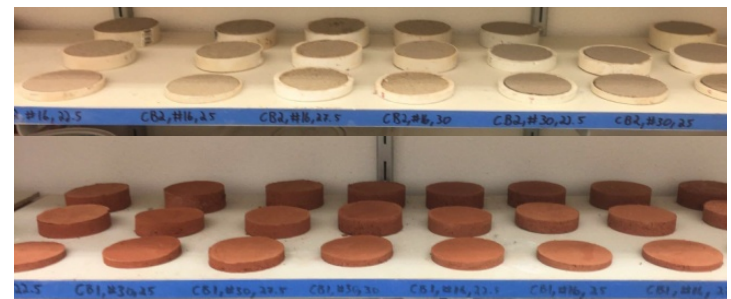

Fig. 3 Variety of clays filters formed during the initial phase of the project.

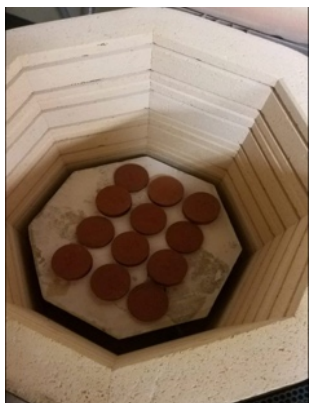

Fig. 4 Firing of the clay filters in a kiln.

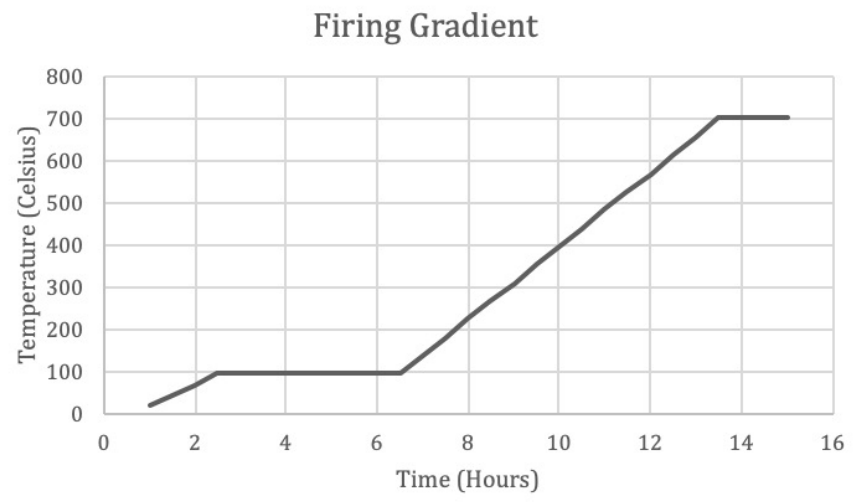

Fig. 5 Kiln temperature during the clay firing process. 
After arriving at the optimal conditions to create the porous clay filters at the end of the 2017 fall semester at WTAMU, the project was continued by two research students from the Mechanical Engineering Program at WTAMU during the 2018 spring semester. These students were given the task to produce a set of clay filters as summarized in Table 1. In addition to creating traditional clay filters, filters with nanoparticles were formed by impregnating the clay-saw dust mixture with silver nanoparticles before the filters were fired in the kiln to a temperature of $700{ }^{\circ} \mathrm{C}$. A total of 16 filters without silver nanoparticles, and 12 filters with silver nanoparticles were created. Figures 6-a and 6-b show typical filters produced using off-white clay material type with and without Ag nanoparticles. The filters in this case were slightly larger and had an average diameter of $8.80 \mathrm{~cm}$. The amount of silver used in each of the silver-embedded filters was 5 grams, but because of the different filter thicknesses, the filter with $1.5 \mathrm{~cm}$ thickness had $5.4 \% \mathrm{Ag}$ concentration by weight, while the filter with $2.25 \mathrm{~cm}$ thickness had a lower Ag concentration of $3.5 \%$.

Table 1. Parameters associated with clay filter disks.

\begin{tabular}{|c|c|c|c|c|c|}
\hline \multirow{2}{*}{$\begin{array}{l}\text { Case } \\
\text { No. }\end{array}$} & \multicolumn{2}{|c|}{ Filters Count } & \multirow{2}{*}{$\begin{array}{l}\text { Mat. } \\
\text { Type }\end{array}$} & \multirow{2}{*}{$\begin{array}{c}\begin{array}{c}\text { Saw Dust } \\
(\% \mathrm{wt})\end{array} \\
\text { Sieve Size }\end{array}$} & \multirow{2}{*}{$\begin{array}{c}\text { Filter } \\
\text { Thickness } \\
(\mathrm{cm})\end{array}$} \\
\hline & $\begin{array}{c}\text { With-out } \\
\text { Ag NP }\end{array}$ & $\begin{array}{c}\text { With Ag } \\
\text { NP/NP Size }\end{array}$ & & & \\
\hline \multirow{2}{*}{$\begin{array}{l}1-b \\
1-a\end{array}$} & \multirow[t]{2}{*}{ ( } & \multirow{2}{*}{$\begin{array}{l}3 / 30-50 \mathrm{~nm} \\
3 / 50-80 \mathrm{~nm}\end{array}$} & \multirow{2}{*}{$\begin{array}{l}\text { Off- } \\
\text { white } \\
\text { clay }\end{array}$} & 27.5 & \multirow[b]{2}{*}{1.5} \\
\hline & & & & No. 16 & \\
\hline \multirow{2}{*}{$\begin{array}{l}2-b \\
2-a\end{array}$} & \multirow{2}{*}{4} & \multirow{2}{*}{$\begin{array}{l}3 / 30-50 \mathrm{~nm} \\
3 / 50-80 \mathrm{~nm}\end{array}$} & \multirow{2}{*}{$\begin{array}{l}\text { Off- } \\
\text { white } \\
\text { clay }\end{array}$} & 25 & \multirow{2}{*}{2.25} \\
\hline & & & & No. 30 & \\
\hline \multirow{2}{*}{3} & \multirow{2}{*}{4} & & \multirow{2}{*}{$\begin{array}{c}\text { Val } \\
\text { Cushing }\end{array}$} & 22.5 & \multirow{2}{*}{0.75} \\
\hline & & & & No. 16 & \\
\hline \multirow{2}{*}{4} & \multirow{2}{*}{4} & & \multirow{2}{*}{$\begin{array}{c}\text { Val } \\
\text { Cushing }\end{array}$} & 22.5 & \multirow{2}{*}{1.5} \\
\hline & & & & No. 16 & \\
\hline
\end{tabular}

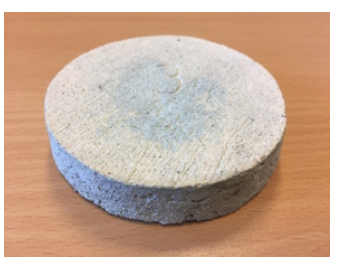

Fig. 6-a Filter embedded with Ag nanoparticles.

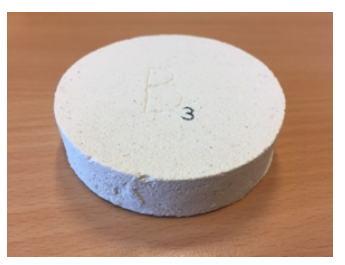

Fig. 6-b Filter without Ag nanoparticles.

Figure 7 shows a sketch of the experimental setup of the water-filtering system. The system consists of two compartments: an upper compartment in which the turbid water is placed, and a lower compartment that collects the clean water. The compartments are made of clear acrylic material. The geometrical shape of the device is cylindrical to simplify the interpretation of the processed data. Figure 8 shows a sketch of a typical clay filter disk impregnated with silver nanoparticles.

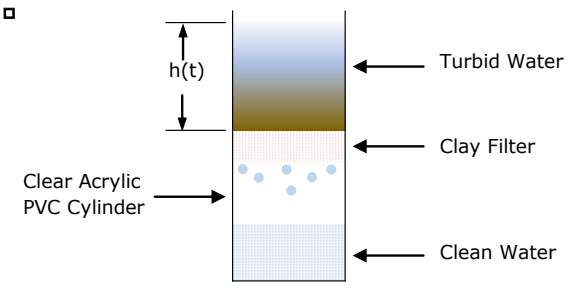

Fig. 7 Experimental setup of the clay filtering system.
口

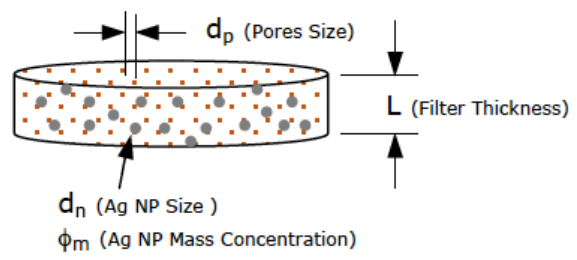

Fig. 8 Sketch of a clay filter disk impregnated with silver nanoparticles. 
The clay filters were first tested during the fall semester for their flow resistance, permeability and turbidity effectiveness. Based on Darcy's law for a gravity-driven flow through a porous media [10], the relationship between flow rate and pressure drop in the liquid column is expressed as follows:

$$
\frac{k}{\mu} \frac{\Delta P}{L}=\frac{Q}{A}
$$

where $k$ is the permeability of the porous material, $\mu$ is the fluid viscosity, $L$ is the thickness of the porous material, $Q$ is the volumetric flow rate, $A$ is the filter cross-sectional area, and $\Delta P$ is the pressure drop across the porous material which is related to the time variable fluid height, $h(t)$ :

$$
\Delta P=\rho g h(t)
$$

$\rho$ is water density, and $\mathrm{g}$ is gravitational acceleration. The time response of a gravity-driven flow is shown to be that of a first order system expressed as follows:

$$
h(t)=h_{o} e^{-t / A R_{L}^{\prime}}
$$

where $h_{o}$ is the initial height of the fluid column, $t$ is time, and $R_{L}^{\prime}$ is given by:

$$
R_{L}^{\prime}=\frac{R_{L}}{\rho g}
$$

where $R_{L}$ is the flow resistance.

The above filters were analyzed for their flow characteristics. Turbid water was poured into a PVC tube fitted above the clay filter disk. The results of the experimental tests are shown in Figs. 9 and 10. Figure 9 shows the time response of the turbid water column height above the disk filter. This data was then used to determine the filters flow resistance and permeability. Figure 10 shows a summary of the filters permeability per unit length as function of the flow resistance.

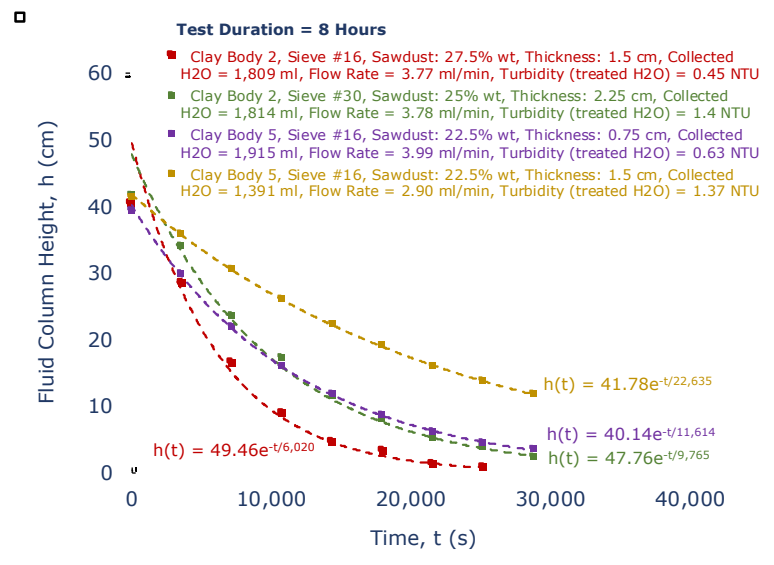

Fig. 9 Tested filters transient flow response.

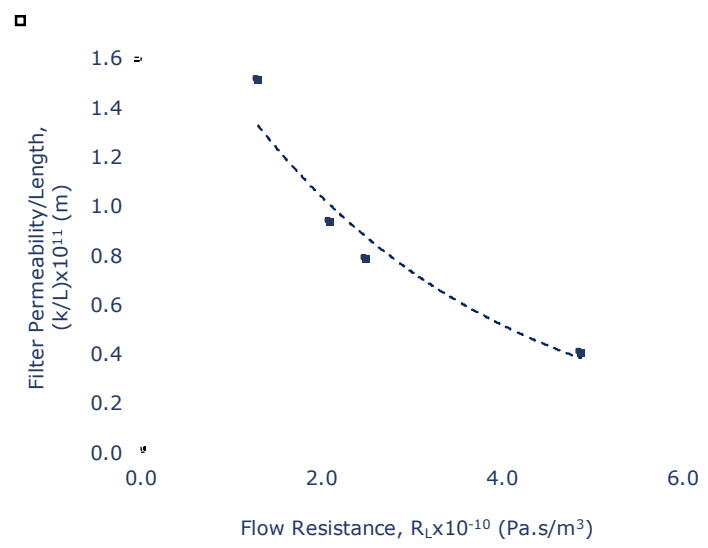

Fig. 10 Tested filters permeability versus flow resistance.

Figure 11 shows the volume of clean water recovered after conducting 24-hours tests on the 4 clay filter configurations shown in Table 1. The results show the volume of recovered water ranged from 4.2 to 5.8 liters per day. Turbidity tests were also performed on the recovered water (Fig. 12). The tests were conducted using Extech TB400 Portable Turbidity Meter. Before the water was filtered, the muddy water that was used had a turbidity ranging from 850 to 950 NTU. Tests revealed that the clay filters were very effective in reducing the 
turbidity of water. For the above four cases, the turbidity of the recovered water ranged from 0.45 to 1.40 NTU. These values are acceptable levels for drinking water. Guidelines established by WHO on water state that the turbidity of drinking water should not be more than 5 NTU, and ideally should be below 1 NTU [1].

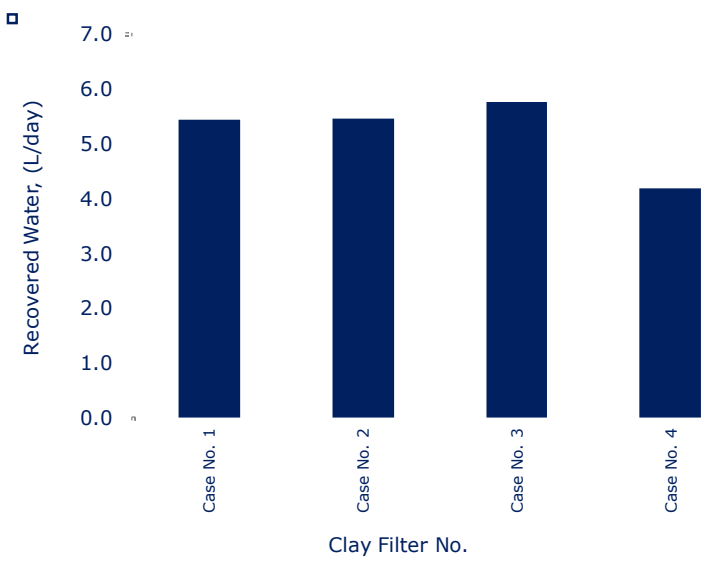

Fig. 11 Recovered water from tested traditional clay filters. (fired at $700{ }^{\circ} \mathrm{C}$ )

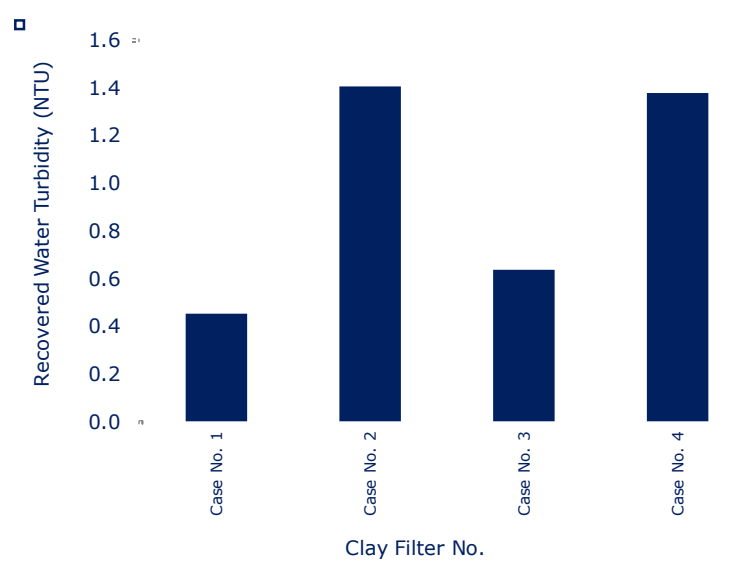

Fig. 12 Turbidity tests on recovered water. (fired at $700{ }^{\circ} \mathrm{C}$ )

\section{PROJECT COMPLETION AT FH JOANNEUM AND THE MEDICAL UNIVERSITY OF GRAZ}

The project was completed at FH JOANNEUM/University of Applied Sciences (FHJ) in Graz, Austria by 6 students from the Production Technology and Organization (PTO) Program during the 2018 summer semester. Dr. Issa, a 2016 U.S. Fulbright Scholar to Austria, was invited as a guest professor to FHJ in summer 2018 to teach Fluid Mechanics Applications course in the PTO undergraduate program. The course focusses on computational and problem solving skills in hydro and aerostatics, and on analysis of in-depth problems in engineering fluid mechanics. Dr. Issa was accompanied by the group leader of the project from WTAMU. A group of six students who were enrolled in the course at FHJ were given the task to complete a project which fulfilled their course requirements. The group was tasked with analyzing the clay water-filtration system from WTAMU.

After analysis of the system, it was determined that alterations had to be made in the firing process of the clay filters. The filters had originally been fired in the kiln at a temperature of $700{ }^{\circ} \mathrm{C}$ at WTAMU. However, after several applications, the filters started to deteriorate, and it was realized that filters had to be fired at a higher temperature, but not high enough to cause a detrimental effect in the use of the clay disks as filters. The traditional clay filters were then fired in Austria for the second time to a temperature of $1,200{ }^{\circ} \mathrm{C}$. Samples of these filters were then tested again for their turbidity and yield rate performance (Fig. 13). Figure 14 shows the yield rate associated with the four different types of filters. In general, the yield rate was slightly lower than those fired to $700{ }^{\circ} \mathrm{C}$. This is not surprising since at higher temperatures silica in the clay starts to fuse causing the clay material to become less porous. Filters that were fired for the second time were also tested again for their turbidity performance, and the results were similar to those shown in Fig. 12. 


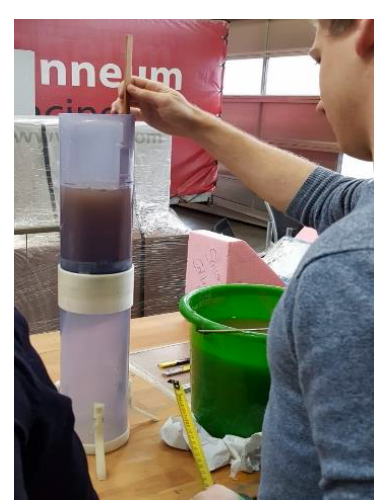

Fig. 13 Water filtration system using PVC tubes. a

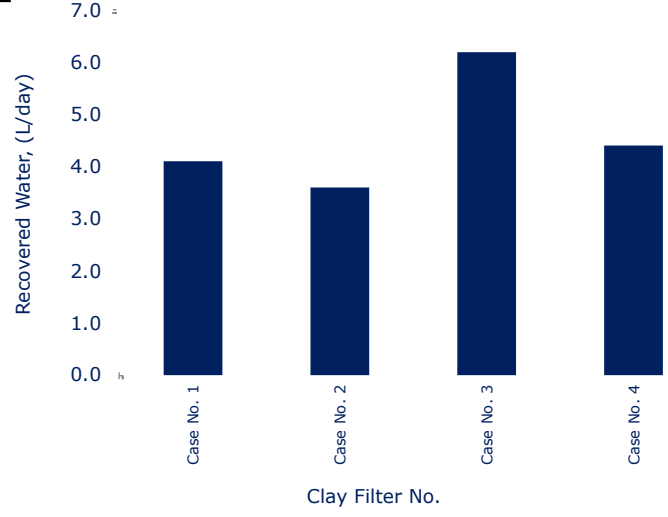

Fig. 14 Recovered water from tested traditional clay filters. (fired at $1,200{ }^{\circ} \mathrm{C}$ )

The silver-embedded filters were assessed for the effectiveness of silver nanoparticles as an anti-bacterial agent. The filters were tested at the Medical University of Graz. Water in the upper compartment of the clay filtering system was inoculated with $\mathrm{E}$. coli bacteria for a concentration ranging from $6.5 \times 10^{7}$ to $5.5 \times 10^{8}$ cells $/ \mathrm{ml}$, and the bacterial cells count was measured in the filtered (lower compartment) and also in the unfiltered water (upper) compartments. The results are shown in Table 2.

Water samples were collected from the unfiltered and filtered water compartments to culture the bacteria cells on Petri dishes. Figure 15 shows the typical growth of E. coli bacteria colonies. The bacteria colonies were numerous in the upper compartment, while the lower compartment shows noticeably less.

Tests conducted on E. coli bacteria show that the silver-embedded clay filters were quite effective in substantially reducing or eliminating the E. coli bacteria in contaminated water. The results also show the smaller the nanoparticle size is, the more effective the filter is. Also the thicker the clay filter is, the better the filter performs in destroying the bacterial cells. This is due to the increase in contact time between the contaminated water and the silver nanoparticles.

Table 2. Testing of the silver-embedded clay filters for their effectiveness in destroying E. coli bacteria cells.

\begin{tabular}{|c|c|c|c|}
\hline Filter Case No. & $\begin{array}{c}\text { Filter } \\
\text { Compartment } \\
\end{array}$ & $\mathrm{CFU} / 250 \mathrm{ml}$ & $\begin{array}{c}\text { Detection Limit/250 } \\
\mathrm{ml}\end{array}$ \\
\hline $1-b$ & $\begin{array}{l}\text { Upper } \\
\text { Lower }\end{array}$ & $\begin{array}{c}5.48 \times 10^{8} \\
0\end{array}$ & $2.5 \times 10^{3}$ \\
\hline $1-\mathrm{a}$ & $\begin{array}{l}\text { Upper } \\
\text { Lower }\end{array}$ & $\begin{array}{l}1.66 \times 10^{8} \\
1.28 \times 10^{6}\end{array}$ & $2.5 \times 10^{3}$ \\
\hline $\begin{array}{c}2-\mathrm{b} \\
\left(1^{\text {st }} \text { Trial }\right)\end{array}$ & $\begin{array}{l}\text { Upper } \\
\text { Lower }\end{array}$ & $\begin{array}{c}7.75 \times 10^{7} \\
0\end{array}$ & $2.5 \times 10^{3}$ \\
\hline $\begin{array}{c}2-\mathrm{b} \\
\left(2^{\text {nd }} \text { Trial }\right)\end{array}$ & $\begin{array}{l}\text { Upper } \\
\text { Lower }\end{array}$ & $\begin{array}{c}6.5 \times 10^{7} \\
0\end{array}$ & $2.5 \times 10^{3}$ \\
\hline $\begin{array}{c}2-\mathrm{a} \\
\left(1^{\text {st }} \text { Trial }\right)\end{array}$ & $\begin{array}{l}\text { Upper } \\
\text { Lower }\end{array}$ & $\begin{array}{c}1.15 \times 10^{8} \\
0\end{array}$ & $<2.5 \times 10^{3}$ \\
\hline $\begin{array}{c}2-\mathrm{a} \\
\left(2^{\text {nd }} \text { Trial }\right)\end{array}$ & $\begin{array}{l}\text { Upper } \\
\text { Lower }\end{array}$ & $\begin{array}{l}8.2 \times 10^{7} \\
3.5 \times 10^{4}\end{array}$ & $<2.5 \times 10^{3}$ \\
\hline
\end{tabular}




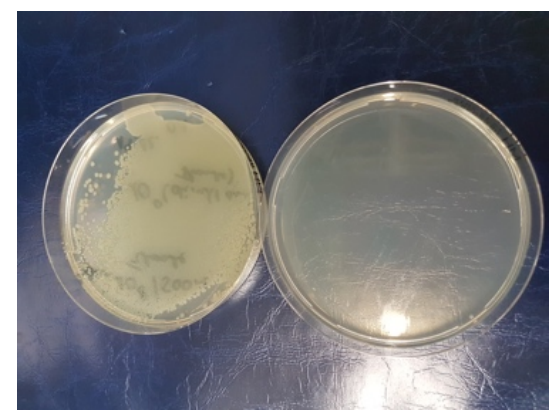

Fig. 15 Typical E. coli bacteria testing on inoculated water and on filtered water.

\section{PROJECT COORDINATION BETWEEN THE TWO UNIVERSITIES}

The project started at WTAMU in Fall 2017 as part of the course requirement in Thermal-Fluid Design, a 3semester credit hour ( $\mathrm{SCH}$ ) course in the U.S. The project weight was $40 \%$ of the course final grade, equivalent 1.2 SCH credits. Sixteen senior mechanical engineering students from WTAMU jump-started the project, but had to hold several Skype meetings during the months of November and December with the potential PTO students (Graz, Austria) in the Fluid Mechanics Applications course before the project was to continue in Summer 2018 at FHJ. The project satisfied the course requirement for the students in Austria, and the $62^{\text {nd }}-$ year engineering students at FHJ who were selected from the Fluid Mechanics Applications course to work on the project received 1 ECTS (European Credit Transfer System) credits, which is equivalent to $0.5 \mathrm{SCH}$. It is important to keep in mind that the Bachelor of Science degree in the Fachhochschule system consists of 6 semesters with a total of 180 ECTS credits (90 SCH credits), while in the U.S. the Bachelor of Science degree consists of 8 semesters with a total of $120 \mathrm{SCH}$ credits. However, the degree in the Fachhochschule system does not include any core curriculum courses (humanities, social science courses, electives, etc...).

During the Skype meetings, the students on both sides discussed the process associated with the formation of the clay filters including the design of the water filtering apparatus. The students at WTAMU had to give frequent updates to the students at FHJ, and deliver a final presentation along with a report at the end of the fall semester in the U.S. Towards the middle of the summer semester at FHJ (Month of May), the group leader of the project at WTAMU accompanied Dr. Issa to Austria to oversee the continuation of the project. The tasks the students in the U.S. worked on included designing the clay filters, and conducting a number of turbidity tests, while the students in Austria worked on evaluating the filtering system, conducting further turbidity tests, and making recommendations to the process associated with the formation of the filters. Testing the silver-embedded clay filters for their effectiveness against E. coli bacteria had to be performed at the Medical University of Graz due to the instrumentation needed at the facility.

\section{AUTHORS FEEDBACK}

This international and multidisciplinary involvement between WTAMU and FHJ gave the students on both sides the opportunity to continue improving their problem-solving, teamwork, and communications skills. The difference between the educational systems of Austrians and American students was a challenge that led to a great learning opportunity for the students on both sides. WTAMU students are focused on theoretical engineering design and analysis while FHJ students are focused on industrial design. The students had to communicate to bridge this gap between their engineering curriculums. In addition to that, the students on both sides had challenges associated with language and cultural background differences. However, such diversity led to greater learning experience for all students.

The project identified with ABET student learning outcomes and particularly outcome 3(3): "an ability to communicate effectively with a range of audiences". It is becoming increasingly important for engineering 
programs in the U.S. to give their students enough preparation to work in an international environment setting. With the increase in globalizations, many recruiters nowadays are looking for good communication skills and international exposure when hiring recent graduates. Even though the teams on both ends (with the exception of the project group leader at WTAMU) did not meet in person, this project created an opportunity for global virtual teams to form. This international experience enlightened and exposed the students to different cultures. That is an essential capability to have as an engineer.

\section{CONCLUSIONS}

Engineering students from the Mechanical Engineering Program at West Texas A\&M University and from the Production Technology and Organization Program at FH JOANNEUM, in Graz, Austria collaborated on an international project to design a ceramic clay filtering system with anti-microbial protection capability for the purification of drinking water in rural areas of India. The project started at WTAMU and concluded at FH JOANNEUM. Students designed the filtering system using acrylic PVC tubing, and came up with 4 different types of clay filter disks based on different mixtures of clay powder material and saw-dust particles. Traditional filters and filters impregnated with silver nanoparticles were formed. Turbidity, yield-rate performance, and E. coli bacteria tests were conducted on the filters. The filters were effective in reducing the turbidity of muddy water from 950 to $0.45 \mathrm{NTU}$ while having a yield rate ranging from around 4 to 6 liters per day. The E. coli bacteria in the contaminated water compartment was reduced from $6.5 \times 10^{7}-5.5 \times 10^{8}$ cells $/ \mathrm{ml}$ to $0-1.26 \times 10^{6}$ cells $/ \mathrm{ml}$ in the filtered water compartment. The international and multidisciplinary focus of the project gave the students on both sides the opportunity to continue improving their problem-solving, teamwork, and communications skills.

\section{ACKNOWLEDGMENT}

The authors would like to thank the following students for their contribution to the project: (from West Texas A\&M University) Treven Fleming, David Walden, Andrew Pillars, Linh Cao, Peter Hughes, Emily Hurst, Andrew Pillers, Caleb Heltenberg, Lewis Hickenbottom, Joseph Mogavero, Matthew Moore, Donavon Morgan, Trevor Myklebust, Justin Rhoades, Pablo Rueda, Dylan Young, and (from FH JOANNEUM, Graz) Birgit Taferner, Thomas Schönauer, Marc Hörtler, Tobias Schneider, Christian Dohr, and Nadja Holeczek.

\section{NOMENCLATURE}

$\begin{array}{llllll}A & \text { filter cross-sectional area } & \left(\mathrm{m}^{2}\right) & \Delta & \text { change } & -- \\ g & \text { gravitational acceleration } & \left(\mathrm{m} / \mathrm{s}^{2}\right) & \rho & \text { fluid density } & \left(\mathrm{kg} / \mathrm{m}^{3}\right) \\ h & \text { fluid column height } & (\mathrm{m}) & \mu & \text { fluid dynamic viscosity } & (\mathrm{Pa} . \mathrm{s}) \\ k & \text { porous material permeability } & \left(\mathrm{m}^{2}\right) & & & \\ L & \text { filter disk thickness } & (\mathrm{m}) & & & \\ P & \text { pressure } & \left(\mathrm{N} / \mathrm{m}^{2}\right) & & & \\ Q & \text { volumetric flow rate } & \left(\mathrm{m}^{3} / \mathrm{s}\right) & & & \\ R_{L} & \text { flow resistance } & \left(\mathrm{N} . \mathrm{s} / \mathrm{m}^{5}\right) & & & \\ t & \text { time } & (\mathrm{s}) & & \end{array}$

\section{REFERENCES}


[1] UNICEF \& WHO Report, Progress on Sanitation and Drinking Water - 2015 Update and MDG Assessment, (2015).

[2] History of the Doulton Ceramic Filter, Retrieved July 18, 2017, from http://www.purewaterproducts.com/articles/history-ofthe-doulton-ceramic-filter.

[3] Lagaron, J., Ocio, M., and Lopez-Rubio, A., Antimicrobial Polymers, New Jersey: John Wiley \& Sons Inc., (2012).

[4] Master, F.J., Agitated Argentums, New Delhi: B. Jain Publishers Ltd., (2006).

[5] Mittelman, A.M., Lantagne, D.S., Rayner, J., and Pennell, K.D., "Silver Dissolution and Release from Ceramic Water Filters", Environ. Sci. Tech., 49, pp. 8515-8522, (2015).

[6] Hajipour, M.J., Fromm, K.M., Ashkarran, A.K., and De Aberasturi, D.J., “Antibacterial Properties of Nanoparticles”, Trends Biotech., 30(10), pp. 499-511, (2012).

[7] Sheng, Z., Van Nostrand, J.D., Zhou, J., and Liu, Y., "The effects of Silver Nanoparticles on Intact Wastewater Biofilms," Front. Microbiol., 6., pp. 1-11, (2015).

[8] Larimer, C., Effect of Silver Nanoparticle Coatings on Mycobacterial Biofilm Attachment and Growth: Implications for Ceramic Water Filters, Ph.D. Thesis, University of Pittsburgh, (2013).

[9] ABET Engineering Accreditation Commission, 2019. Criteria for Accrediting Engineering Programs, Retrieved July 14, 2019, from http:://www.abet.org/accreditation, (2019)

[10] Whitaker, S., 1986, "Flow in porous media I: A theoretical derivation of Darcy's law", Transport Porous Med., 1, pp. 3-25, (1986). 